This Journal is available in Telkom University online Journals

Jurnal Manajemen Indonesia

\title{
The Effect of Social Media Marketing, Word of Mouth, and Effectiveness of Advertising on Brand Awareness and Intention to Buy
}

Siti Maria ${ }^{1}$, Tommy Pusriadi ${ }^{2}$, Yundi Permadi Hakim ${ }^{3}$, Dio Caisar Darma ${ }^{4}$

${ }^{1}$ Faculty of Economic and Bussines, Mulawarman University, Samarinda, Indonesia (75119)

2,3,4 Samarinda High College of Economics Science, Samarinda, Indonesia (75242)

\begin{abstract}
The purpose of this research is to analyze the direct effect of social media marketing, word of mouth, and the effectiveness of advertising on brand awareness and its impact on intention to buy, either directly or indirectly. The data source of 50 respondents, obtained from the customers who use transportation services in Samarinda. Models using path analysis programs and data are processed through SPSS version 23. Result from this research based on sub-stucture model 1 reveal that social media marketing and the effectiveness of advertising directly has a significant positive effect on brand awareness. From sub-structure 2, the effectiveness of advertising and brand awareness directly has a significant positive effect on intention to buy. Finally, social media marketing and effectiveness of advertising indirectly has a significant positive effect on intention to buy through brand awareness.
\end{abstract}

Keywords-Advertising, Brand Awareness, Intention to Buy, Social Media Marketing, Word of Mouth.

\begin{abstract}
Abstrak
Tujuan dari penelitian ini adalah untuk menganalisis efek langsung social media marketing, word of mouth, dan efektivitas iklan pada brand awareness dan dampaknya terhadap intention to buy, baik secara langsung maupun tidak langsung. Sumber data berasal dari 50 pelanggan layanan transportasi di wilayah Kota Samarinda. Penelitian menggunakan model analisis jalur dan data diproses melalui SPSS versi 23. Penelitian ini menyatakan model sub-struktur 1, diketahui social media marketing dan efektivitas iklan secara langsung berpengaruh positif dan signifikan terhadap brand awareness. Dari sub-struktur 2, efektivitas iklan dan brand awareness secara langsung berpengaruh positif dan signifikan terhadap intention to buy. Terakhir, social media marketing dan efektivitas iklan secara tidak langsung berpengaruh positif dan signifikan terhadap intention to buy melalui brand awareness pelanggan.
\end{abstract}

Kata kunci-Brand Awareness; Efektivitas Iklan; Minat Beli; Pemasaran Sosial Media; Word of Mouth;

\section{INTRODUCTION}

Social media revolution has changed the traditional communication as well as marketing communication. The role of social networks in daily communication has increased and they have become number one communication tool among consumers. Users now spend more and more time with these social media platforms and they share and learn information about brands, products and services (Blackshaw \& Nazzaro, 2006). These new communication tools provide users to be an active part of the communication process comparing the passive role in traditional communication. With social media platforms providing two-way communication between consumers and brands has evolved (Berthon et al., 2008) in marketing communication process. And users have become the influencer part of that communication (Constantinides \& Fountain, 2008) comparing the traditional marketing communication. As a result, brands put heavy communication and campaigns on social media in order to interact with users and consumers. 
This new marketing communication creates challenges and opportunities for brands. Purchase decisions, awaraness of products and brands are influenced by social media interactions. The information shared by other consumers play an important role in purchase behavior, post purchase behavior as well as the experience gained from using product or service (Divol et al., 2012). Moreover, information provided by brands are not number one sources for consumers in the process of buying decision. Now consumers heavily rely on the information provided by other consumers rather than brands (Chi, 2011).

Kartajaya (2007) states the current number of internet users in Indonesia has increased significantly from 2013 to 2014. It can be seen that there are 82 million people using the internet in 2013, then followed by the growth of social media. Indonesia is one of the countries whose social media growth is very rapid. Social media has now become a trend to spread a issue, knowledge or information quickly to internet user.

Based on data from Central Bureau of Statistics of East Kalimantan Province (2017), Samarinda City which is the capital of East Kalimantan Province, has reached 828,303 population, with density 1,155.99 people/km2 in 2016. Of that population, many of this number are resident immigrant so that mobility of people that in and out from Samarinda are enormous and this facts make many transportation companies to have branches or open representative companies in Samarinda to catch this oppoturnity. One of these services is Go-Jek.

Go-Jek can be ordered through Go-Jek application which can be downloaded through play store or app store. Within 1 month this application has managed to reach 150 thousand downloads, with a rating of 1 out of 5 stars. For the payment, it has 2 ways payment of cash or use Go-Jek credit. Go-Jek credit is a Go-Jek payment method that is made easy and can be used to pay for all services. Until June 2015, Go-Jek applications have been downloaded as much as 400 thousand times in google play on the android operating system. With the existing phenomenon that people prefer to use this new transportation services to look for and use, then conventional transportation (microlet and other transportation services) is reduced for the wearer. Go-Jek in the Samarinda City makes the community becomes less use of conventional transportation services, resulting in a gap in terms of income-generating, innovation that did have an impact on the surrounding community, the occurrence of violence in this case vigilant because Go-Jek deliver passengers or goods in the message to the destination. Problem is, Go-Jek was confronted by other competitors continue to happen violence/beating at the time (occurred in Juanda street and others).

From the background and problems mentioned earlier, the purpose of this research are: (1) Analyzing the effect of social media marketing, word of mouth and direct effectiveness of advertising on Go-Jek brand awareness; (2) Analyzing the effect of social media marketing, word of mouth, effectiveness of advertising and brand awareness directly on intention to buy Go-Jek; (3) Analyzing the effect of social media marketing, word of mouth and effectiveness of advertising indirectly on intention to buy through Go-Jek brand awareness.

\section{LITERATURE REVIEW}

\section{A. Social Media Marketing - Brand Awareness}

The use of social networking sites as a corporate internet marketing tool to capture the community in the virtual world is widely used company. Social networking sites are used because they have exceptional connectivity between customers and communities that have already formed in it (Assael, 2001). Companies like Dell, Starbucks, and others use social networking sites as a promotional medium to build brand awareness.

As a marketing tool, social networks offer significant opportunities to build brand consumer relationships in marketing (Vukasovic, 2013). In recent years, many businesses have seen social media as one of the most effective ways to communicate and empower consumers to create distinctive brand identities and increase consumer-brand communications (So et al., 2017). Hartzel et al. (2011) have noted that interactive marketing strategies which are using social media links such as Facebook and Twitter will positively affect brand image and create a leverage effect between brand and consumer. The viral effect among social media users allows the brand to be discussed and widely known among a large number of users (Kumar et al., 2007; Sharma \& Verma, 2018). Tsimonis \& Dimitriadis (2014) have revealed that brand awareness is one of the major outputs expected from businesses' social media marketing activities. The findings that pointed out by Fanion (2011) have shown that social media is a significant tool in constituting and increasing brand awareness. Seo \& Park (2018) have found out that social media marketing activities in the airline industry positively affect brand awareness and brand image. 


\section{B. Word of Mouth - Brand Awareness}

Study done by Ha (2004) indicates that electronic word of mouth has a particular strength, which can raise the awareness, and subsequently affect the consumer behaviour. In addition, word of mouth can positively enhance brand awareness and brand association respectively (Page \& Lepkowska, 2002). According to Jansen et al. (2009), electronic word of mouth plays a vital role in expressing brand satisfaction and would have impact on brand awareness. However, theoretical interrelationships among electronic word of mouth, brand association and brand awareness have been proven, but mediating relationship among these three constructs have not been evaluated.

Another study conducted by Severi et al. (2014), in this research brand equity is measured through brand awareness, brand associations, brand loyalty, brand image and perceived quality. The result of this research is word of mouth significantly influence brand awareness.

\section{Effectiveness of Advertising - Brand Awareness}

Advertising is an attempt to make consumers familiar and have awareness of a product by providing information about the product and its superiority compared to competitors (Shimp, 2003). Research conducted by Gunawan \& Dharmayanti (2014), the result of this research is advertising have positive and significant effect to brand awareness.

Advertising dollars are spent to generate specific advertising messages, PR copy, or promotional activities. For example, for a manufacturer of desktop PCs we might distinguish between spending on television advertising, radio advertising, newspaper advertising and vertical trade advertising. All this activity reaches some consumers at some point, and they will or will not pay attention and process these messages. This then may lead to a number of advertising effects. Three types of effects are possible: (1) cognitive effects; (2) affective effects; and (3) behavioral effects. Specific examples in these categories are brand awareness (cognitive), brand positioning (cognitive, affective), consideration-liking (affective), and brand choice (behavioral) respectively. The extent to which consumers who are exposed to advertising will go through these stages will depend on their ability and motivation to process the information and messages offered to them (Petty \& Krosnick, 2014). Awareness has been found to be a necessary condition for advertising effectiveness.

\section{Social Media Marketing - Intention to Buy}

Interactive internet customer relationships and services through discussion forums, emails, chats, social networking sites make consumers closer to and familiar with the companies and products the company offers. Consumers who feel satisfied and secure the quality of a particular company products will be easier to decide to buy the product. This is based on the trust that is formed and awakened from the introduction of products through the internet and after sales service satisfactory products.

As a means to provide communication, selling and relationship to their customers, banks have now turn to social media. This two way communications platform is perfect for sharing information and opinions. Social media is considered more sincere to consumers because it communicates what the brand is instead of try to control its image. This type of interaction enhanced positive attitudes towards the brands, affects stronger commitment and purchase-decision making process (Hutter et al., 2013). Further, it has been found that social media affects brand's sales performance (Zhu \& Zhang, 2010). Accordingly, purchase intention influenced by social media marketing (Kim \& Ko, 2010).

\section{E. Word of Mouth (WOM) - Intention to Buy}

WOM messages can effectively reduce the risk and uncertainty when purchasing products so that consumer purchase intention and decision making can be further influenced (Chatterjee, 2001; Wang et al., 2012; Tsimonis \& Dimitriadis, 2014). Chevalier \& Mayzlin (2006) found that online communications significantly influence the product purchase intention of consumers. Berger et al. (2010) found the significant relationship between the quantity of online reviews and favourable purchase intention of consumers towards the specified brand. Lee et al. (2011b) found that products with more favourable reviews generally sell better. However, if the number of negative reviews about product increases, consumers will learn its many disadvantages and lead to a negative effect on purchase intentions (Park \& Lee, 2008). However, it is also predictable that negative reviews are more influential than positive messages about the products and that negative messages also play an 
important role in consumer decision making (Lee et al., 2011a). Thus, WOM communication is extremely useful for customers to build up their buying decision regarding a particular product or brand.

As an internet-based version of WOM, opinions, online reviews, product consumption experiences, the new information presented from the perspective of consumers who have purchased and used the product, have become a major informational source for consumers. New marketing channels, such as review sites, social networking sites and blogs offer new possibilities for marketers to promote their products or services. According to Nielsen (2013), consumer trust in online advertising is growing. WOM recommendations are perceived as most trustworthy by consumers (84\%), but also trust in advertising on branded websites (69\%) and trust in online consumer opinions is growing (68\%). In this digital world, the concept of eWOM gaining popularity by leaps and bounds and thus, organizations must frame effective internet-mediated communication strategies for gaining competitive advantage.

\section{F. Effectiveness of Advertising - Intention to Buy}

All types of advertising, at least, provides basic information about a product or service, its availability, its features and benefits. This information increase the chances that a person will purchase goods or services advertised to him/her (Schiffman \& Kanuk, 2009). The viewers or potential users also get the benefit of making a buying choice by assessing various substitutes of the product or service though advertisement (Hafeez et al., 2017). The scholar of advertising and marketing argue that when customers evaluate goods or services positively, they have a tendency of purchase intentions towards the advertised service or product (Adelaar et al., 2003; Beatty \& Ferrell, 1998; Bowden, 2009; Cheung \& To, 2017; Dittmar et al., 1996; Hausman, 2000; Qazi et al., 2017). However, an advertisement which is aligned with potential users' needs and wants can result in stimulating purchase intentions and ultimate buying of the advertised products/services (Ducoffe, 1996; Pollay \& Mittal, 1993; Swani et al., 2003, Dahlén, 2001).

Advertising has a positive impact on consumer behavior specially on framing purchase intentions of the target viewers of that advertising (Kotler, 1989). Such association of advertising with purchase intentions is found by the almost all studies in this domain (Drossos et al., 2014; Grewal et al., 1998; Helm \& Evans, 2016; Lee et al., 2011a; Pechmann \& Stewart, 1990; Petty \& Krosnick, 2014).

\section{G. Brand Awareness - Intention to Buy}

Consumers buy products with certain brands they know because they hope that the product they buy is really a quality-tested product and can be used to meet future expectations. So, it can be concluded that the desire/buying interest is determined by the level of introduction of a consumer to the product brand (Durianto et al., 2001). Consumers will only buy products with brands that they know, because consumers tend to be difficult to try something new and prefer a product that is definitely brand and tested its quality (Andriyanto \& Haryanto, 2010).

Research conducted by Chi et al. (2009), the study examines the impact of brand awareness on consumer buying interest and the influence of mediated perceptions of quality and brand loyalty to brand awareness and buying interest. The results of this study indicate that brand awareness has a positive influence on consumer buying interest.

\section{H. Social Media Marketing - Brand Awareness - Intention to Buy}

Purchase intention refers to what a consumer thinks or considers to buy (Blackwell et al., 2001). An individual with intention to purchase a product demonstrates higher actual purchasing rates as compared to customers who have no intention of purchasing (Brown et al., 2003). Consumers' favorable or unfavorable attitudes and belief towards a brand and purchase intention in electronic environment, for example in social media, are depending on the amount of negative and positive online reviews of that brand (Lee et al., 2008). Brand image is a set of relationship that consumers hold in their memory about a brand and it is reflected by the brand associations apprehended in consumer's mind (Keller, 1993). It is a set of beliefs held by consumers based on the attributes of each brand and it represents the product quality which can eventually affects the purchase intention of the consumers, particularly in the context of social media networks (Reza \& Samiei, 2012).

E-WOM referred to the consumers' communication all over the internet about the product information (Thurau-Hennig et al., 2004). It provides a basic for group individuals to establish social associations among 
them and for the setting of virtual groups. Thurau-Hennig et al. (2004) defined e-WOM as any positive or negative comment made by previous, potential or actual consumers about a product, company or a brand via the Internet, for example e-communication among users of social media. It is a form of word of mouth communication about a product or brand among users in internet or social media setting (Charo et al., 2015).

\section{Word of Mouth - Brand Awareness - Intention to Buy}

Sallam (2015) in his study of the effect of corporate image on WOM: the role of customer satisfaction and trust determine a conceptual framework and to create customer's word of mouth by building corporate image and to illustrate the role of mediating variable which are namely consumer's satisfaction and trust. And in his study on an investigation of corporate image effect on WOM: the role of customer satisfaction and trust, he found that corporate image was found to have a positive impact on customer's satisfaction.

Williams et al. (2012) stated that the association between WOM and corporate reputation is most pronounced within customer service departments, sales force and communications arenas of the organization, including PR and its use of cause-related marketing in his study of relating word-of-mouth to corporate reputation.

Some studies proved that PWOM plays an important role in store image perception, brand selection and etc. WOM is described as the process that allows consumers to share information and opinions that direct buyers toward and away from specific products, brands and services (Hawkins et al., 2004). The basic idea behind WOM is that information about products, services, stores, companies and so on can spread from one consumer to another. In its broadest sense, WOM communication includes any information about a target object (e.g. company, brand) transferred from one individual to another either in person or via some communication medium (Brown et al., 2005). Yavas \& Shemwell (1996) propose WOM as one of the main sources of image formation.

\section{J. Effectiveness of Advertising - Brand Awareness - Intention to Buy}

Creating awareness is the primary role of advertising such as communicating to target consumers on products, services, experiences, ideas, and so forth, offered by the companies (Manickam, 2014). Online advertisements outperform the print advertisements because the web's vividness and interactivity characteristics cater for differences in how advertisements are processed in the two media (Belanche et al., 2017). Compared to print, the authors add that online advertising offers more stimuli and could thus potentially effectively create brand awareness and keep theuser's attention and interest longer. Advertising is the primary revenue stream for many of the free services provided to internet users and isessential to the continued economic sustainability ofmany services, such as email, news, and search engines (Castro, 2012).

Any person or organization that uses any service or commodity. Consumer plays a vital role in the economic system as he pays to buy the goods or services produced. If consumer demand is not there producers will lose the motivation to produce and it will affect the economic system (Cobb-Walgren et al., 1995; Ehrenberg et al., 2004; Esch et al., 2006; Hakala et al., 2012). Purchase intention means to plan to buy a good or attain a service. It refers to the desire of a customer to buy a particular product of a certain brand. The most recognized consumer purchase intention model was presented by Engel et al. (1995). This model describes the purchase process in five stages: (1) Identification of the problem; (2) Searching information; (3) Evaluating the substitutes; (4) Making decision; and (5) Behavior after purchase. Engel et al. (1995) divide the purchase intention into "Unplanned buying, partially-Planned buying and Fully Planned buying". Consumers sometimes buy on their gut feelings and the decision is made at the store. This type of decision can be categorized into an unplanned buying decision. Partially-planned buying means that consumers decide the product category before going to the store, and decides about the brand after arriving at the store. Then comes the fully planned buying decision, it means the consumer decides about the product and the brand before entering the store (Hoyer \& Brown, 1990; Jalilvand et al., 2011; Oh, 2000; Pappu \& Quester, 2006; Wu et al., 2011).

\section{RESEARCH DESIGN}

\section{A. Analysis Model}

Path analysis was used for analyzing the data in this study. The use of path analysis methods allows researchers to test several endogenous variables at once with exogenous variables (Ferdinand, 2011). 
The reason for using path analysis model was because there are influencing mediations among exogenous variables with endogenous variables. This study consisted of three variables, namely exogenous variables (social media marketing, word of mouth, and effectiveness of advertising), mediating variable (brand awareness), while those that act as endogenous variable are intention to buy. Intervening variable are brand awareness.

According to Kerlinger (2002), a variable is called an intervening variable if these variables also influence the relationship between exogenous variables and endogenous variables. Testing the mediation hypothesis can be done by a procedure developed by the sobel test. This test is done by testingthe strength of the indirect effect of the exogenous variable $(\mathrm{X})$ to the endogenous variable $(\mathrm{Z})$ through the intervening variable $(\mathrm{Y})$ (Preacher, Rucker, \& Hayes, 2007).

\section{B. Population and Sample}

The population of this study are consumers who use Go-jek services and domiciled in the Samarinda City. The number of population in this study is not known for certain, whereas researchers want speed, low cost, and easy in determining the sample. From that reason, the researcher uses non-probability sampling, where not all members of the population have the same opportunity to be elected as a sample member. This will make it easier for researchers to determine the sample members, because the selection of sample members is chosen by the researchers themselves with certain criteria.

The large number of samples in the unlimited population was set by 50 respondents. Sugiyono (2009) indicated that minimum number of samples for the correlation data of at least 30 samples. The sampling technique used to determine the characteristics of respondents is purposive sampling, which in sampling is done on the basis of a particular purpose or consideration.

\section{Operational Definition}

The object of this research is limited to this research are several factors in building brand awareness and intention to buy Go-Jek Samarinda customers during August-November 2018. To clarify the operational definition of research indicators was shown in the Table 1:

Table 1. Operational Summary and Variable Indicator

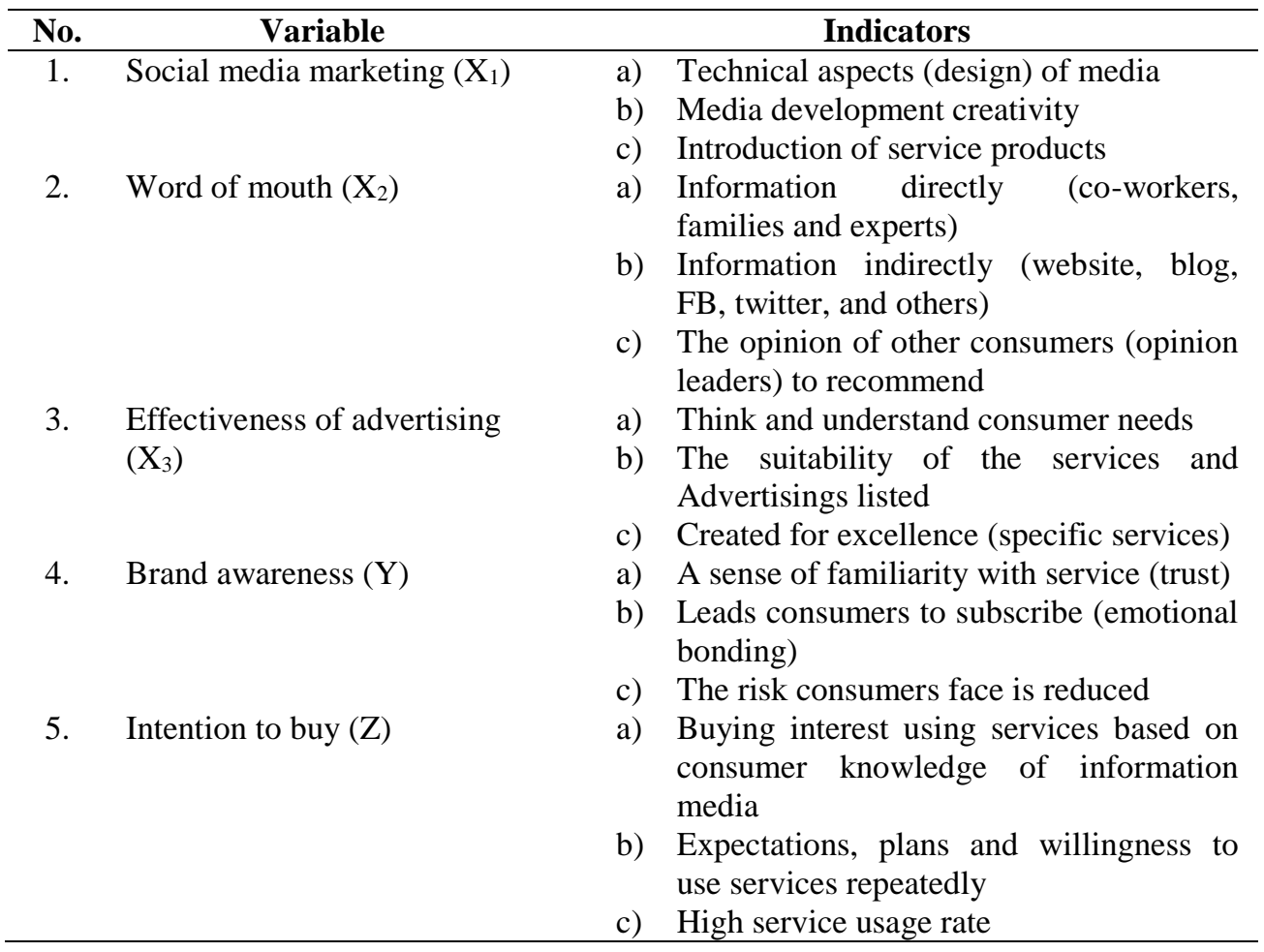




\section{Research Instruments}

Research instrument that has been used in this study are questionnaires with 5 likert scale. Table 2 shown the score that used to measure respondent responses.

Table 2. Data Measurement Scale

\begin{tabular}{lc}
\hline \multicolumn{1}{c}{ Answer Options } & Score \\
\hline Very Good & 5 \\
Good & 4 \\
Enough & 3 \\
Bad & 2 \\
Very Bad & 1 \\
\hline
\end{tabular}

In the research questionnaire, the number of respondents did not start from the number 0 , but from the numbers 1 through 5. Analysis in this study was done by using index analysis, where the consumer perception of the variables used in this study. Thus, each variable is based on the average score (index) categorized in the range of scores based on three bok methode (Ferdinand, 2006).

For data analysis model, path analysis were used with some prior testing, such as data quality test (validity and realibiltas test). The purpose of data analysis methods is to interpret and draw conclusions from a number of collected data. Researchers use SPSS software version 23.0 to process and analyze data research results.

\section{ANALYSIS AND DiSCUSSION}

\section{A. Results of Research Instruments}

The results of testing social media marketing, word of mouth, effectiveness of advertising, brand awareness and intention to buy variables, with the number of statements as much as 3 items based on each variable. It is known from the validity test that the whole $r$ value for the whole item question is bigger than the value of $r$ table $=0.197$ in the two-tailed df is: $98(n-2=100-2)$. Criteria testing, that is if the value of $\mathrm{r}$ arithmetic $>\mathrm{r}$ table value, then all items variable question is valid or can be used as research instrument. The analysis results are described in Table 3.

Table 3. Test of Variable Validity

\begin{tabular}{lllll}
\hline No. & Statement & r-value & r-table & Information \\
\hline 1. & $\mathrm{X} 1_{(1)}$ & 0.891 & 0.197 & Valid \\
2. & $\mathrm{X} 1_{(2)}$ & 0.874 & 0.197 & Valid \\
3. & $\mathrm{X} 1_{(3)}$ & 0.867 & 0.197 & Valid \\
4. & $\mathrm{X} 2_{(1)}$ & 0.831 & 0.197 & Valid \\
5. & $\mathrm{X} 2_{(2)}$ & 0.795 & 0.197 & Valid \\
6. & $\mathrm{X} 2_{(3)}$ & 0.814 & 0.197 & Valid \\
7. & $\mathrm{X} 3_{(1)}$ & 0.848 & 0.197 & Valid \\
8. & $\mathrm{X} 3_{(2)}$ & 0.811 & 0.197 & Valid \\
9. & $\mathrm{X} 3_{(3)}$ & 0.833 & 0.197 & Valid \\
10. & $\mathrm{Y}_{(1)}$ & 0.735 & 0.197 & Valid \\
11. & $\mathrm{Y}_{(2)}$ & 0.810 & 0.197 & Valid \\
12. & $\mathrm{Y}_{(3)}$ & 0.766 & 0.197 & Valid \\
13. & $\mathrm{Z}_{(1)}$ & 0.839 & 0.197 & Valid \\
14. & $\mathrm{Z}_{(2)}$ & 0.844 & 0.197 & Valid \\
15. & $\mathrm{Z}_{(3)}$ & 0.887 & 0.197 & Valid \\
\hline
\end{tabular}

In addition to testing validity, a research instrument needs another test that is reliability. Reliability testing of the research questionnaire is intended to know or analyze whether the statistical questionnaire used from each variable studied otherwise reliable. Table 4 shown reliability test based on SPSS output. 
Table 4. Variable Reliability Test

\begin{tabular}{cc}
\hline Cronbach's Alpha & Nof Items \\
\hline .914 & 3 \\
\hline
\end{tabular}

The reliability analysis results from 15 points statement on questionnaire were studied based on the magnitude of each r-count (r-Alpha) value. From the two independent variables studied, the results obtained values greater than the value of r-table $=0.914$ (coefficient alpha $>60 \%$ significance level or 0.6 ), then the questionnaire used has been reliable.

\section{E. Result of Path Analysis}

Path analysis used in research to proved hypothesis about factors influencing brand awareness and intention to buy which are limited to variables: social media marketing, word of mouth and effectiveness of advertising by consumers who use Go-Jek service in Samarinda, either directly or indirectly. In sub-structural analysis first model, will be calculated what is the direct effect of social media marketing and word of mouth and effectiveness of advertising on brand awareness to Go-Jek consumer in Samarinda.

Table 5. Model Estimation (Sub-Structure 1)

\begin{tabular}{|c|c|c|c|c|c|}
\hline \multirow[b]{2}{*}{ Model } & \multicolumn{2}{|c|}{$\begin{array}{c}\text { Unstandardized } \\
\text { Coefficients }\end{array}$} & \multirow{2}{*}{$\begin{array}{c}\begin{array}{c}\text { Standardized } \\
\text { Coefficients }\end{array} \\
\text { Beta }\end{array}$} & \multirow{2}{*}{$\mathrm{t}$} & \multirow{2}{*}{ Sig. } \\
\hline & $\mathrm{B}$ & Std. Error & & & \\
\hline 1 (Constant) & 2.259 & .857 & & 2.637 & .010 \\
\hline $\mathrm{X} 1$ & .237 & .079 & .263 & 2.980 & .004 \\
\hline $\mathrm{X} 2$ & .154 & .088 & .156 & 1.757 & .082 \\
\hline $\mathrm{X} 3$ & .418 & .086 & .440 & 4.866 & .000 \\
\hline
\end{tabular}

Based on the equation, it can be concluded that all independent variables have a positive effect on brand awareness (Table 5).

$$
\mathrm{Y}=0.263 \mathrm{X}_{1}+0.156 \mathrm{X}_{2}+0.440 \mathrm{X}_{3}+0.466 \mathrm{e}_{1}
$$

The sub-structural analysis second model will be calculated as to whether the direct effect of social media marketing and word of mouth, as well as the effectiveness of advertising and brand awareness of intention to buy to Go-Jek consumers in Samarinda.

Table 6. Model Estimation (Sub-Structure 2)

\begin{tabular}{|c|c|c|c|c|c|}
\hline \multirow[b]{2}{*}{ Model } & \multicolumn{2}{|c|}{$\begin{array}{c}\text { Unstandardized } \\
\text { Coefficients }\end{array}$} & \multirow{2}{*}{$\begin{array}{c}\text { Standardized } \\
\text { Coefficients } \\
\text { Beta }\end{array}$} & \multirow{2}{*}{$\mathrm{t}$} & \multirow{2}{*}{ Sig. } \\
\hline & B & Std. Error & & & \\
\hline $1 \quad$ (Constant) & 1.904 & .882 & & 2.158 & .033 \\
\hline $\mathrm{X} 1$ & .046 & .083 & .048 & .553 & .581 \\
\hline $\mathrm{X} 2$ & -.059 & .089 & -.057 & -.671 & .504 \\
\hline $\mathrm{X} 3$ & .232 & .095 & .230 & 2.434 & .017 \\
\hline $\mathrm{Y}$ & .635 & .102 & .599 & 6.259 & .000 \\
\hline
\end{tabular}

Based on the equation, it can be concluded that all independent variables have a positive effect intention to buy (Table 6).

$$
Z=0.048 X_{1}-0.057 X_{2}+0.230 X_{3}+0.599 Y+0.405 e_{2}
$$

Based on the equation, it can be concluded that all variables: social media marketing, effectiveness of advertising and brand awareness has a positive effect on brand awareness. Whereas, only word of mouth variables has a negative effect. The calculation number using path model is as follows: 
1) Direct causal effect

a) Social media marketing $\left(\mathrm{X}_{1}\right)$ on brand awareness $(\mathrm{Y})$ is 0.263

b) Word of mouth $\left(\mathrm{X}_{2}\right)$ on brand awareness $(\mathrm{Y})$ is 0.156

c) Effectiveness of Advertising $\left(\mathrm{X}_{3}\right)$ on brand awareness $(\mathrm{Y})$ is 0.440

d) Social media marketing $\left(\mathrm{X}_{1}\right)$ on intention to buy $(\mathrm{Z})$ is 0.048

e) Word of mouth $\left(X_{2}\right)$ on intention to buy $(Z)$ is -0.057

f) Effectiveness of Advertising $\left(X_{3}\right)$ onintention to buy $(Z)$ is 0.230

g) Brand awareness (Y) on intention to buy $(\mathrm{Z})$ is 0.599

2) Inderect causal effect

a) The effect of social media marketing $\left(\mathrm{X}_{1}\right)$ on intention to buy $(\mathrm{Z})$ through brand awareness $(\mathrm{Y})$ is 0.263 $\mathbf{x} 0.599=0.157$. With sobel test, the indirect effect of variable $\mathrm{X}_{1}$ on $\mathrm{Z}$ through $\mathrm{Y}$ is significant $(0.003$ $<0.05)$.

b) The effect of word of mouth $\left(\mathrm{X}_{2}\right)$ on intention to buy (Z) through brand awareness $(\mathrm{Y})$ is $0.156 \mathbf{x} 0.599$ $=0.093$. With sobel test, the indirect effect of variable $\mathrm{X}_{2}$ on $\mathrm{Z}$ through $\mathrm{Y}$ is not significant $(0.089>$ $0.05)$.

c) The effect of effectiveness of Advertising $\left(\mathrm{X}_{3}\right)$ on intention to buy $(\mathrm{Z})$ through brand awareness $(\mathrm{Y})$ is $0.440 \times 0.599=0.263$. With sobel test, the indirect effect of variable $\mathrm{X}_{3}$ on $\mathrm{Z}$ through $\mathrm{Y}$ is significant $(0.000<0.05)$.

\section{3) Total effect}

Based on the results of path analysis on the sub-structure model 1 and 2 obtained the value of beta coefficients, illustrated the path diagram for total effect are shown in figure 1 below.

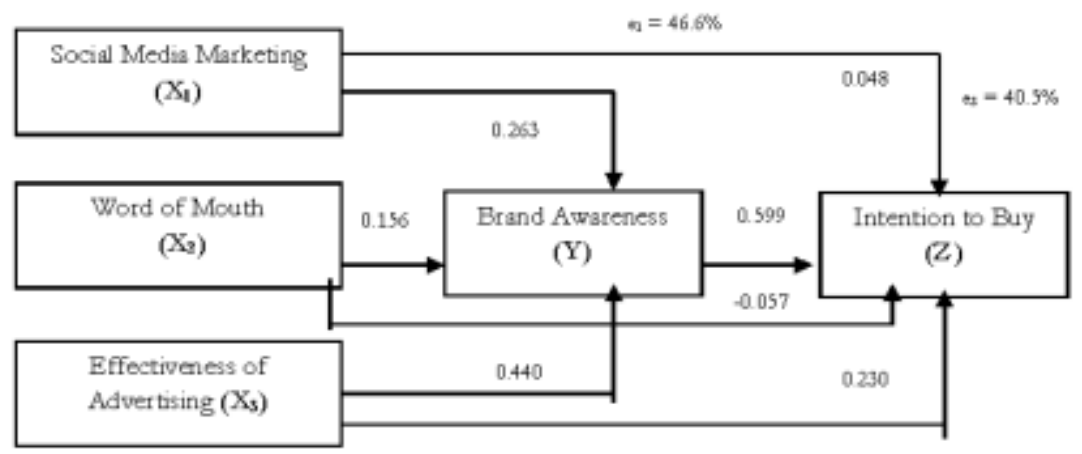

Figure 1. Results Calculation of Path Analysis Model

The calculation of direct and indirect effect, groupings are done in Table effect between variables as follows (Table 7).

Table 7. Comparative Results of Direct, Indirect and Total Effect

\begin{tabular}{lccccc}
\hline Correlation & $\begin{array}{c}\text { Direct } \\
\text { Effect }\end{array}$ & Sig. & $\begin{array}{c}\text { Indirect Effect } \\
\text { throught Y }\end{array}$ & Sig. & $\begin{array}{c}\text { Total } \\
\text { Effect }\end{array}$ \\
\hline $\mathrm{X}_{1}-\mathrm{Y}$ & 0.263 & 0.004 & - & - & 0.263 \\
$\mathrm{X}_{2}-\mathrm{Y}$ & 0.156 & 0.082 & - & - & 0.156 \\
$\mathrm{X}_{3}-\mathrm{Y}$ & 0.440 & 0.000 & - & - & 0.440 \\
$\mathrm{X}_{1}-\mathrm{Z}$ & 0.048 & 0.581 & - & - & 0.048 \\
$\mathrm{X}_{2}-\mathrm{Z}$ & -0.057 & 0.504 & - & - & -0.057 \\
$\mathrm{X}_{3}-\mathrm{Z}$ & 0.230 & 0.017 & - & - & 0.230 \\
$\mathrm{Y}-\mathrm{Z}$ & 0.599 & 0.000 & - & - & 0.599 \\
$\mathrm{X}_{1}-\mathrm{Y}-\mathrm{Z}$ & - & - & $0.263 \times 0.599=0.157$ & 0.003 & 0.007 \\
$\mathrm{X}_{2}-\mathrm{Y}-\mathrm{Z}$ & - & - & $0.156 \times 0.599=0.093$ & 0.089 & -0.005 \\
$\mathrm{X}_{3}-\mathrm{Y}-\mathrm{Z}$ & - & - & $0.440 \times 0.599=0.263$ & 0.000 & 0.060 \\
\hline
\end{tabular}


Result on table 7 inferred the sub-structural path analysis model 1 and 2, word of mouth either indirectly negatively and insignificant to intention to buy (Z). Brand awareness (Y) is not a mediating variable between the two relationships of these variables. Social media marketing $\left(\mathrm{X}_{1}\right)$ and effectiveness of Advertising $\left(\mathrm{X}_{3}\right)$ variable have no positive and significant impact on intention to buy $(\mathrm{Z})$. Thus, brand awareness $(\mathrm{Y})$ is the mediation variable between the two independent variables.

\section{F. Discussion}

\section{1) The Effect of Social Media Marketing Directly on Brand Awareness}

Path analysis results show that social media marketing is directly has a positive and significant effect on GoJek brand awareness in Samarinda. The use of social networking sites as Go-Jek's internet marketing tool to capture the Samarinda community in cyberspace has been used by company. Social networking sites are used because they have great connectivity between customers and communities that have already formed. Companies like Go-Jek in Samarinda use social networking sites as promotional media to build brand awareness of users.

The use of social media through instagram, facebook and blog and official website from Go-Jek has given a real effect in building a brand awareness that is able to touch consumers. The use of sophisticated electronic devices in this era such as mobile phones, all are able to access and reach Go-Jek services in Samarinda for reservations, service cancellations to see other links related to the service company.

This finding is relevant to the study by Seo \& Park (2018), have found out that social media marketing activities in the airline industry positively affect brand awareness and brand image.

\section{2) The Effect Word of Mouth Directly on Brand Awareness}

Path Analysis results show that word of mouth directly has a positive and insignificant effect on Go-Jek brand awareness in Samarinda. As times get more sophisticated by accessing sundries that relate to Go-jek services through the media, it will leave a message (track record) service from its customers. For now, the WOM factor does feel real because it is positively related. However, seeing its influence insignificantly on brand awareness, needs to be a major concern. This is due to the characteristic of the consumers, especially the respondents who have been interviewed because the recall is entirely from Samarinda which is the center of East Kalimantan Province. Generally, a reflection of urban dwellers who are more fond of assessing these services from online and mass media, as well as heterogeneous (widespread) make WOM variables less significant effect to assess the brand awareness factor from person to person.

WOM is how to harness the power of people to build Go-Jek brand awareness in Samarinda. WOM is an input and Brand Awareness is the output. Thus, the outcome of WOM is to create consumer awareness of the Go-Jek Company brand. This finding is relevant to the study by Page \& Lepkowska (2002), found that word of mouth can positively enhance brand awareness and brand association respectively.

\section{3) The Effect Effectiveness of Advertising Directly on Brand Awareness}

The result of path analysis shows that the effectiveness of advertising has a positive and significant effect on Go-Jek brand awareness in Samarinda. The advertising world is certainly not something new, even a major commodity of print and online media to attract companies to advertise goods or services that are sold in a language (sentence) that attracts many people. Each business enthusiast would want to look good and make the product traded as number one, compared to the others. So is the splendor of Go-Jek ads that consistently appear in some media to be close to potential customers. Like print media that almost every day market advertising at a certain rate according to the number of sentence, line or paragraph usage.

Advertising from Go-Jek in Samarinda is considered effective, it will be easy if we use a view that is an advertising is called effective if the ad can achieve the goals to be achieved by advertisers. A good or effective ad is an ad created for a specific customer and an advertising that thinks and understands the customer's need to re-purchase Go-Jek services. This finding is relevant to the study by Gunawan \& Dharmayanti (2014), the result of this research is advertising have positive and significant effect to brand awareness.

\section{4) The Effect of Social Media Marketing Directly on Intention to Buy}

Path analysis results show that social media marketing directly has a positive and insignificant effect on intention to buy Go-Jek in Samarinda. Promotion programs and the introduction of Go-Jek's profile and history in Samarinda through social networking sites or websites will make consumers better understand and know a 
company more closely. Travel Go-jek through internet marketing has adopted a more customized (one to one approach) that makes consumers feel specialized by the service. Consumers will feel comfortable and Go-Jek in Samarinda will be easier to get closer to consumers to get important information for the company.

In practice, social media marketing can not have a significant impact on intention to buy. Despite having a positive relationship, intention to buy factor can not run directly to attract respondents. The fact is because prospective consumers through social media not yet know for sure the evidence in Go-jek services, but only a mere curiosity. For that, it takes a real picture like a short video (message and impression) of the consumer service users and not just words and sentences that have not been felt visually. This finding is relevant to the study by Kim \& Ko (2010), found that purchase intention influenced by social media marketing.

\section{5) The Effect Word of Mouth Directly on Intention to Buy}

Path analysis results show that word of mouth is directly has a negative and insignificant effect on intention to buy Go-Jek in Samarinda. This research proves that Word of Mouth tends to be ineffective in the marketing of Go-Jek services in Samarinda. Marketers find that WOM has affected about 2/3 of consumer goods sales, and even surveys show that $69 \%$ of consumers use this service on the advice of someone they already know. No ad or seller will be able to persuade a consumer persuasive about the quality of services from Go-Jek except for a friend, acquaintance, or old customer.

Buying interest is also based on Go-Jek's consumer knowledge in Samarinda which they get from media information about the brand and that is expected by the consumer is a travel service that has been tested its quality and can be used to meet its future. However, in this result the WOM variable does not prove it and it has a negative and insignificant impact on Go-Jek's consumer WOM compared to others. This finding is relevant to the study by Lee et al. (2011b), predictable that negative reviews are more influential than positive messages about the products and that negative messages also play an important role in consumer decision making.

\section{6) The Effect Effectiveness of Advertising Directly on Intention to Buy}

The result of path analysis shows that the effectiveness of advertising directly has a positive and significant effect on intention to buy Go-Jek in Samarinda. In order for advertising to attract and communicate with the audience in a certain way, so that results generated. Ads that are made as attractive as possible can generate interest in the brand image brought by the ad, thus there is the motivation and desire to make a purchase and try to use the product. Go-Jek in Samarinda formed should be clear and has an advantage when compared with other travel services competitors.

The advertisings made by Go-Jek in such a way have attracted imaginative, original interest and possess certain characteristics and persuasive, so that consumers or others are voluntarily motivated to take action as advertisers want. The high effectiveness of the ads the higher the Go-Jek brand image itself. The higher the effectiveness of advertising, the higher the buying interest, the higher the brand image the higher the interest indirectly affect the consumer's desire to make a repeat purchase and there are differences from competitors.

This finding is relevant to the study by Adelaar et al. (2003), Beatty \& Ferrell (1998), Bowden (2009), Cheung \& To (2017), Dittmar et al. (1996), Hausman (2000), Qazi et al. (2017), found that the scholar of advertising and marketing argue that when customers evaluate goods or services positively, they have a tendency of purchase intentions towards the advertised service or product.

\section{7) The Effect of Brand Awareness Directly on Intention to Buy}

Path analysis result shows that brand awareness directly has a positive and significant effect on intention to buy Go-Jek in Samarinda. Consumers buy products with certain brands they know because they hope that the product they buy is really a quality-tested product and can be used to meet future expectations. So it can be concluded, that the desire/buying interest is determined by the level of consumer recognition of service brands Go-jek in Samarinda.

Consumers will only use services with brands they know like Go-Jek than others, because consumers in Samarinda tend to find it hard to try something new and prefer Go-Jek's service that is definitely brand and quality tested. If it is so, it is very difficult for other competitors in the world of travel services to compete with Go-jek. This finding is relevant to the study by Chi et al. (2009), found that brand awareness has a positive influence on consumer buying interest. 


\section{8) The Effect of Social Media Marketing Indirectly on Intention to Buy through Brand Awareness}

Path analysis results show that social media marketing indirectly has a positive and significant effect on intention to buy through Go-Jek brand awareness in Samarinda. Interactive internet connections and customer service through discussion forums, emails, chats, social networking sites make consumers in Samarinda closer and get to know Go-Jek and the services at company offers.

Transformation of social media marketing today, is not difficult to attract users of Go-Jek services, because brand awareness has been formed. Brand awareness variables are not only a value added, but also as a value chain or primary motor in driving the intensity of intention to buy from the research respondents.

This finding is relevant to the study by Reza \& Samiei (2012), based on the attributes of each brand and it represents the product quality which can eventually affects the purchase intention of the consumers, particularly in the context of social media networks.

\section{9) The Effect Word of Mouth Indirectly on Intention to Buy through Brand Awareness}

Path analysis results show that word of mouth indirectly has a positive and insignificant effect on intention to buy through Go-Jek brand awareness in Samarinda. Social media marketing is generally informal and previously tested to give a real effect on a person's buying interest. Supposedly, the presence of WOM is to be an intact combination that is relevant to touch Go-Jek's consumer in Samarinda. The dynamics of WOM through brand awareness; it seems formal impression for consumers, because the results of field proof did not give a domino effect significantly (although having a positive relationship).

Go-Jek consumers in Samarinda will tend to believe in recommendation of use but not through WOM channels, but through formal promotional methods. This is because the providers of social media marketing and advertising world are believed to have given enough power to its own bargaining power. WOM in these findings just outweigh the fancy ads made by Go-jek Samarinda.

This finding is relevant to the study by Hawkins et al. (2004), found that WOM is described as the process that allows consumers to share information and opinions that direct buyers toward and away from specific products, brands and services.

\section{0)The Effect Effectiveness of Advertising Indirectly on Intention to Buy through Brand Awareness}

Path analysis results show that the effectiveness of advertising indirectly has a positive and significant effect on intention to buy through Go-Jek brand awareness in Samarinda. Advertising is an effort to make consumers familiar and have awareness of Go-Jek services by providing information about services and superiority compared to competitors in Samarinda and surrounding areas. The purpose of advertising is to persuade consumers to do something, usually to buy a product. In order for advertising to attract and communicate with the audience in a certain way, so that results generated.

The ads made by Go-Jek in Samarinda are as interesting as they may have attracted interest in the brand image brought by the ad, thus there is a motivation and desire to make purchases and try to use travel services. The image formed should be clear and have an advantage when compared to its competitors. When differences and brand advantages are confronted with other brands, there is a Go-Jek brand position in the eyes of consumers. This finding is relevant to the study by Castro (2012), found that online advertising offers more stimuli and could thus potentially effectively create brand awareness, keep theuser's attention, and interest longer.

\section{CONCLUSIONS AND RECOMMENDATIONS}

\section{A. Conclusions}

This research suggests if social media marketing and effectiveness of advertising directly has a positive and significant effect on building Go-Jek brand awareness. The effectiveness of advertisement and brand awareness has directly positive and significant on intention to buy Go-Jek. Social media marketing and effectiveness of advertising indirectly has a positive and significant effect on intention to buy through Go-Jek brand awareness. 


\section{B. Recommendations}

Go-Jek has had to do a lot of better changes through advertising and brand image to keep consumers believing, so the brand image is maintained and the products offered will be stronger in the travel market. Effectiveness of advertising in this research is the most dominant factor in influencing brand awareness and intention to buy variables, either directly or indirectly. The advertising contained in various media are required to be more creative and increase the frequency of advertising further upgraded. For the next researcher, is expected to examine with other variables outside the indicators that have been studied in order to obtain more varied results that may affect brand awareness and intention to buy.

\section{REFERENCES}

Adelaar, T., Chang, S., Lancendorfer, K. M., Lee, B., \& Morimoto, M. (2003). Effects of media formats on emotions and impulse buying intent. Journal of Information Technology, 18(4), 247-266.

Andriyanto, R. D., \& Haryanto, J. O. (2010). Analisis Pengaruh Internet Marketing terhadap Pembentukan Word of Mouth dan Brand Awareness untuk Memunculkan Intention to Buy. Journal of Technology Management, 9(1), 20-35.

Assael, H. (2001). Consumer Behavior and Marketing Action. 6th ed. Thomson Learning. Boston: MA.

Beatty, S. E., \& Ferrell, M. E. (1998). Impulse Buying: Modeling its Precursors. Journal of Retailing, 74(2), 169-191.

Belanche, D., Flavián, C., \& Pérez-Rueda, A. (2017). Understanding Interactive Online Advertising: Congruence and Product Involvement in Highly and Lowly Arousing, Skippable Video Ads. Journal of Interactive Marketing, 37(C), 75-88.

Berger, J., Sorensen, A. T., \& Rasmussen, S. J. (2010). Positive Effects of Negative Publicity: When Negative Reviews Increase Sales. Marketing Science, 29(5), 815-827.

Blackwell, R. D., Miniard, P. W., \& Engel, J. F. (2001). Consumer Behavior. New York: Harcourt College Publishers.

Bowden, J. L. (2009). The Process of Customer Engagement: A Conceptual Framework. Journal of Marketing Theory and Practice, 17(1), 63-74.

Brown, M., Pope, N., \& Voges, K. (2003). Buying or Browsing? An Exploration of Shopping Orientations and Online Purchase Intention. European Journal of Marketing, 37(11/12), 1666-1684.

Brown T. J., Barry T. E., Dacin, P. A., \& Gunst, R. F. (2005). Spreading the Word: Antecedents of Consumers Positive Word-of-Mouth Intentions and Behaviors in a Retailing Context. Journal of Academy of Marketing Science, 33(2), 123-138.

Castro, D. (2012). Why ITIF Rejects Your “Do Not Track” Request. Information Technology \& Innovation Foundation (ITIF). Retrieved April 28, 2019, from https://itif.org/publications/2012/09/27/why-itif-rejectsyour-\%E2\%80\%9Cdo-not-track\%E2\%80\%9D-request.

Central Bureau of Statistics East Kalimantan Province. (2017). Distribution and Population Density by Regency/City in East Kalimantan Province 2016. BPS Catalog: 1102001.64. Samarinda: Sekar Mulya.

Charo, N., Sharma, P., Shaikh, S., Haseeb, A., \& Sufya, M. Z. (2015). Determining the impact of ewom on brand image and purchase intention through adoption of online opinions. International Journal of Humanities and Management Sciences, 3 (1), 41-46.

Chatterjee, P. (2001). Online reviews: Do Consumers Use Them?. Advances in Consumer Research, 28(1), 129133.

Chevalier, J., \& Mayzlin, D. (2006). The Effect of Word of Mouth on Sales: Online Book reviews. Journal of Marketing Research, 43(3), 345-354.

Cheung, M. F., \& To, W. M. (2017). The Influence Of The Propensity To Trust On Mobile Users, Attitudes Toward In-App Advertisements: An Extension Of The Theory Of Planned Behavior. Computers in Human Behavior, 76(C), 102-111.

Chi, H. H. (2011). Interactive Digital Advertising Vs Virtual Brand Community: Exploratory Study Of User Motivation And Social Media Marketing Responses In Taiwan. Journal of Interactive Advertising, 12(1), 44-61.

Chi, H. K, \& Yeh, H. R., \& Yang, Y. T. (2009). The impact of brand awareness on consumer purchase intention: The mediating effect of perceived quality and brand loyalty. The Journal of International Management Studies, 4(1), 135-144. 
Cobb-Walgren C. J., Ruble C. A., \& Donthu, N. (1995). Brand Equity, Brand Preference, And Purchase Intent. Journal of Advertising, 24(3), 25-40.

Dahlén, M. (2001). Banner Advertisements through a New Lens. Journal of Advertising Research, 41(4), 23-30.

Dittmar, H., Beattie, J., \& Friese, S. (1996). Objects, Decision Considerations And Self Image In Men's And Women's Impulse Purchases. Acta psychologica, 93(1), 187-206.

Divol, R., Edelman, D., \& Sarrazin, H. (2012). Demystifying Social Media. McKinsey Quarterly. Retrieved April 13, 2019, from http://www.mckinsey.com/insights/marketing_sales/demystifying_social_media.

Drossos, D. A., Kokkinaki, F., Giaglis, G. M., \& Fouskas, K. G. (2014). The effects of product involvement and impulse buying on purchase intentions in mobile text advertising. Electronic Commerce Research and Applications, 13(6), 423-430.

Ducoffe, R. H. (1996). Advertising Value And Advertising On The Web. Journal of Advertising Research, 36(5), 21-35.

Durianto, D., Sugiarto., \& Sitinjak, T. (2001). Strategi Menaklukkan Pasar Melalui Riset Ekuitas dan Perilaku Merek. Jakarta: Gramedia.

Ehrenberg, A. S., Uncles, M. D., \& Goodhardt, G. J. (2004). Understanding Brand Performance Measures: Using Dirichlet Benchmarks. Journal of Business Research, 57(12), 1307-1325.

Engel J. F., Blackwell R. D., \& Miniard, P. W. (1995). Consumer Behavior ( ${ }^{\text {th }}$ edn.). New York: Dryden Press.

Esch F. R., Langner, T., Schmitt B. H., \& Geus, P. (2006). Are Brands Forever? How Brand Knowledge And Relationships Affect Current And Future Purchases. Journal of Product \& Brand Management, 15(2), 98105.

Fanion, R. (2011). Social Media Brings Benefits To Top Companies. Central Penn Business Journal, 27(3), 7677.

Ferdinand, A. (2006). Structural Equation Modeling Dalam Penelitian Manajemen. Semarang: Badan Penerbit Universitas Diponegoro.

Ferdinand, A. (2011). Metode Penelitian Manajemen: Pedoman Penelitian untuk Penulisan Skripsi, Tesis, dan Disertasi Ilmu Manajemen (Edisi 3). Semarang: AGF Books.

Grewal, D., Monroe, K. B., \& Krishnan, R. (1998). The Effects Of Price-Comparison Advertising On Buyers, Perceptions Of Acquisition Value, Transaction Value, And Behavioral Intentions. The Journal of Marketing, 62(2), 46-59.

Gunawan, F. A., \& Dharmayanti, D. (2014). Analysis of the Influence of Television Advertising Usage and Endorser in Establishing Brand Awareness and Purchase Intention of Products POND'S Men. Journal of Petra Marketing Management, 2(1), 1-14.

Hafeez, H. A., Manzoor, A., \& Salman, F. (2017). Impact of Social Networking Sites on Consumer Purchase Intention: An Analysis of Restaurants in Karachi. Journal of Business Strategies, 11(1), 171-172.

Ha, H. Y. (2004). Factors Influencing Consumer Perceptions of Brand Trust Online. Journal of Product \& Brand Management, 13(5), 329-342.

Hakala, U., Svensson, J., \& Vincze, Z. (2012). Consumer-Based Brand Equity And Top-Of-Mind Awareness: A Cross-Country Analysis. Journal of Product \& Brand Management, 21(6), 439-451.

Hartzel, K. S., Mahanes, C. J., Maurer, G. J., Sheldon, J., Trunick, C., \& Wilson, S. J. (2011). Corporate Posts and Tweets: Brand Control in Web 2.0. Journal of Information \& Knowledge Management, 10(1), 51-58.

Hausman, A. (2000). A Multi-Method Investigation Of Consumer Motivations In Impulse Buying Behavior. Journal of Consumer Marketing, 17(5), 403-426.

Hawkins D. I., Best, R., \& Coney, K. A. (2004). Consumer Behavior: Building Marketing Strategy. Boston: McGraw-Hill.

Helm, C., \& Evans, L. (2016). Understanding the Effect of Television Advertising on Women's Attitudes and Purchase Intentions Towards Beer: A Study of Three Major Brands. Presented at Academy of Marketing Brand SIG $11^{\text {th }}$ Global Brand Conference, University of Bradford (27-29 Apr 2016). WestminsterResearch. Retrieved Mei 5, 2019, Retrieved from http://www.westminster.ac.uk/westminsterresearch.

Hoyer, W. D., \& Brown S. P. (1990). Effects of Brand Awareness on Choice for a Common, Repeat-Purchase Product. Journal of Consumer Research, 17(12) 141-148.

Jalilvand, M. R., Samiei, N., \& Mahdavinia, S. H. (2011). The Effect of Brand Equity Components on Purchase Intention: An Application of Aaker's Model in the Automobile Industry. International Business and Management, 2(2), 149-158.

Jansen, B. J., Zhang, M., Sobel, K., \& Chowdury, A. (2009). Twitter Power: Tweets as Electronic Word of Mouth. Journal of the Association Society for Information Science and Technology, 60(11), 2169-2188. 
Kartajaya, H. (2007). Boosting Loyalty Marketing Performance: Menggunakan Teknik Penjualan, Customer Relationship Management, dan Servis untuk Mendongkrak Laba. Bandung: PT Mizan Pustaka.

Keller, K. L. (1993). Conceptualizing, Measuring, and Managing Customer-Based Brand Equity. Journal of Marketing, 57(1), 1-22.

Kerlinger, F. N. (2002). Asas-asas Penelitian Beharioral. Edisi Ketiga. Yogyakarta: Gadjah Mada University Press.

Kim, A. J., \& Ko, E. (2010). Impacts Of Luxury Fashion Brand's Social Media Marketing On Customer Relationship And Purchase Intention. Journal of Global Fashion Marketing, 1(3), 164-171.

Kotler, P. (1989). From Mass Marketing To Mass Customization. Planning Review, 17(5), 10-47.

Kumar, V., Petersen, J. A., \& Leone, R. P. (2007). How Valuable Is Word Of Mouth?. Harvard Business Review, 85(10), 139-146.

Lee, J., Park, D. H., \& Han, I. (2008). The Effect Of Negative Online Consumer Reviews On Product Attitude: An Information Processing View. Electronic Commerce Research and Applications, 7(3), 341-352.

Lee, J., Lee, J. N., \& Shin, H. (2011a). The Long Tail Or The Short Tail: The Category-Specific Impact Of Ewom On Sales Distribution. Decision Support Systems, 51(3), 466-479.

Lee, J., Park, D. H., \& Han, I. (2011b). The Different Effects Of Online Consumer Reviews On Consumers' Purchase Intentions Depending On Trust In Online Shopping Malls: An Advertising Perspective. Internet research, 21(2), 187-206.

Manickam, S. A. (2014). Do Advertising Tools Create Awareness, Provide Information, And Enhance Knowledge? An Exploratory Study. Journal of Promotion Management, 20(3), 291-310.

Nielsen. (2013). Under the Influence: Consumer Trust in Advertising. Retrieved April 30, 2019, from https://www.nielsen.com/us/en/insights/news/2013/under-the-influence-consumer-trust-inadvertising.html.

Oh, H. (2000). The Effect Of Brand Class, Brand Awareness, And Price On Customer Value And Behavioral Intentions. Journal of Hospitality \& Tourism Research, 24(2), 136-162.

Page, C., \& Lepkowska, W. E. (2002). Web Equity: A Framework For Building Consumer Value In Online Companies. Journal of Consumer Marketing, 19(3), 231-248.

Pappu, R., \& Quester, P. (2006). Does Customer Satisfaction Lead To Improved Brand Equity? An Empirical Examination Of Two Categories Of Retail Brands. Journal of Product \& Brand Management, 15(1), 4-14.

Park, D. H., \& Lee, J. (2008). eWOM Overload And Its Effect On Consumer Behavioral Intention Depending On Consumer Involvement. Electronic Commerce Research and Applications, 7(4), 386-398.

Pechmann, C., \& Stewart, D. W. (1990). The Effects Of Comparative Advertising On Attention, Memory, And Purchase Intentions. Journal of Consumer Research, 17(2), 180-191.

Petty, R. E., \& Krosnick, J. A. (2014). Attitude Strength: Antecedents and Consequences. $1^{\text {st }}$ Edition. New York: Psychology Press. Retrieved Mei 17, 2019, from https://doi.org/10.4324/9781315807041.

Preacher, K. J., Rucker, D.D., \& Hayes, A. F. (2007). Adressing Moderated mediation Hypotheses: Theory, Methods, \& Prescription. Multivariate Behavioral Research, 42(1), 185 -227

Pollay, R. W., \& Mittal, B. (1993). Here's the Beef: Factors, Determinants and Segments in Consumer Criticism of Advertising. Journal of Marketing, 57(3), 99-114.

Qazi, T. Y., Ohtaki, S., \& Munir, M. (2017). Social Network Advertisements and Purchase Intentions: a Case of Mobile Facebook Users in Pakistan. Academic Research International, 08(01), 60-69.

Reza, J. M., \& Samiei, N. (2012). The Effect of Word of Mouth on Inbound Tourists' Decision for Traveling to Islamic Destinations (The Case of Isfahan as a Tourist Destination in Iran). Journal of Islamic Marketing, $3(1), 12-21$.

Sharma, S., \& Verma, H. V. (2018). Social Media Marketing: Evolution and Change. Githa Heggde, and G. Shainesh. Social Media Marketing Emerging Concepts and Applications (s. 19-36). Singapore: Palgrave Macmillan.

Sallam, M. A. (2015). The Effect Of Corporate Image On Wom: The Role Of Customer Satisfaction And Trust Proposing A Conceptual Framework. International Journal of Economics, Commerce and Management, 3(12), 331-340.

Schiffman, L. G., \& Kanuk, L. L. (2009). Consumer Behaviour. Edition 10. New Jersey: Pearson Prentice Hall.

Severi, E., Ling, K. C., \& Nasermoadeli, A. (2014). The Impact of Electronic Word of Mouth on Brand Equity in the Context of Social Media. International Journal of Business and Management, 9(8), 84-96.

Shimp, T. A. (2003). Advertising, Promotion \& Supplemental Aspects of Integrated Marketing Communications $\left(6^{\text {th }} e d\right)$. Mason, Ohio: Thomson South-Western. 
So, K. K., Wu, L., Xiong, L., \& King, C. (2017). Brand Management In The Era Of Social Media: Social Visibility Of Consumption And Customer Brand Identification. Journal of Travel Research, 57(6)1-16.

Sugiyono. (2009). Metode Penelitian Kuantitatif, Kualitatif, dan R\&D. Bandung: Alfabeta.

Swani, K., Milne, G., \& Brown, P. B. (2013). Spreading The Word Through Likes On Facebook: Evaluating The Message Strategy Effectiveness Of Fortune 500 Companies. Journal of Research in Interactive Marketing, 7(4), 269-294.

Thurau-Hennig, T., Gwinner, K. P., Walsh, G., \& Gremler, D. D. (2004). Electronic Word-Of-Mouth Via Consumer Opinion Platforms: What Motivates Consumers To Articulate Themselves On The Internet?. Journal of Interactive Marketing, 18(1), 38-52.

Tsimonis, G., \& Dimitriadis, S. (2014). Brand Strategies In Social Media. Marketing Intelligence \& Planning, 32(3), 328-344.

Vukasovic, T. (2013). Building Successful Brand By Using Social Networking Media. Journal of Media and Communication Studies, 5(6), 56-63.

Wang, X., Yu, C., \& Wei, Y. (2012). Social Media Peer Communication and Impacts on Purchase Intentions: A Consumer Socialization Framework. Journal of Interactive Marketing, 26(4), 198-208.

Williams, M., Buttle, F. A., \& Biggemann, S. (2012). Connecting Word-of-Mouth to Corporate Reputation. Public Communication Review, 2(2), 3-16.

Wu, P. C., Yeh, G. Y., \& Hsiao, C. R. (2011). The Effect Of Store Image And Service Quality On Brand Image And Purchase Intention For Private Label Brands. Australasian Marketing Journal (AMJ), 19(1), 30-39.

Yavas U., \& Shemwell, D. J. (1996). Competing For Patients And Profit. Journal of Health Care Marketing, 16(2), 30-37.

Zhu, F., \& Zhang, X. (2010). Impact Of Online Consumer Reviews On Sales: The Moderating Role Of Product And Consumer Characteristics. Journal of Marketing, 74 (2), 133-148. 